\title{
Konstruksi Ilmu Sejati Orangtua Kepada Keluarga Melalui Komunikasi Keluarga dan Analisis Teori CMM
}

\author{
Editya Meshita ${ }^{1}$, Darsono Wisadhirana ${ }^{2}$, dan Antoni*3 \\ 1,2,3 Universitas Brawijaya \\ Email: edityameshita11@gmail.com¹,darsono_wisa@ub.ac.id²,ant_ui@yahoo.com*3 \\ *corresponding author
}

Keywords:

Real Science

Coordinated Management of

Meaning (CMM Theory)

Family Communications

\begin{abstract}
The discussion about the Parent Construction Process towards family members is a widely discussed issue. The Importance of Communication between the two in everyday life is very necessary to establish harmony and intimacy in the family. This study aims to find out about the True Science Construction of Parents Against Family Members using the Coordinated Management of Meaning Analysis. This study uses a constructivist interpretative approach with qualitative methods. The findings of this study were that Family Members learned lessons about True Science through Parents by visiting the Sejati Science College, visiting True Science relatives, inserting the teachings of True Science through daily conversation, and conducting light discussions every day. The contribution of this research is Family Communication is the most important role in the process of the Construction of the True Science Teachings done by parents to family members. This study produces data that family communication has a role in the construction of the teachings of the True Science of Parents (fathers) with family members resulting in an attachment to the process of discussion about the teachings of True Science. The suggestion given by researchers is that it is necessary to conduct similar research on social groups other than the adherents of the True Sciences to find out the development of kebatinan flow in the modern era today in family communication.
\end{abstract}

\begin{abstract}
ABSTRAK
Diskusi mengenai Proses Konstruksi Orangtua terhadap anggota keluarga menjadi isu yang banyak diperbincangkan. Pentingnya Komunikasi diantara keduanya dalam kehidupan sehari-hari merupakan hal yang sangat diperlukan untuk menjalin kerukunan dan keintiman dalam keluarga. Penelitian ini bertujuan untuk mengetahui mengenai Konstruksi Ilmu Sejati Orangtua Terhadap Anggota Keluarga dengan menggunakan Analisis Teori Coordinated Management of Meaning. Penelitian ini menggunakan pendekatan Interpretatif konstruktivis dengan metode Kualitatif. Temuan pada penelitian ini yaitu Anggota Keluarga mendapatkan pelajaran mengenai Ilmu Sejati melalui Orangtua dengan cara mengunjungi Perguruan Ilmu Sejati, mengunjungi kerabat penganut Ilmu Sejati, menyisipkan ajaran-ajaran Ilmu Sejati melalui percakapan sehari-hari, serta melakukan diskusi ringan setiap hari. Kontribusi penelitian ini adalah Komunikasi Keluarga merupakan peran terpenting dalam proses Konstruksi Ajaran Ilmu Sejati yang dilakukan orangtua kepada anggota keluarga. Penelitian ini menghasilkan data bahwa komunikasi keluarga memiliki peranan dalam konstruksi ajaran Ilmu Sejati Orangtua (ayah) dengan anggota keluarga sehingga terjadi keterikatan dalam proses diskusi mengenai ajaran Ilmu Sejati. Saran yang diberikan peneliti yaitu perlu dilakukan penelitian sejenis pada kelompok sosial selain keluarga penganut Ilmu Sejati untuk mengetahui perkembangan aliran kebatinan di era Modern saat ini dalam komunikasi keluarga.
\end{abstract}

Copyright (C) 2018 Channel Jurnal Komunikasi. All right reserved. 


\section{PENDAHULUAN}

Komunikasi dalam kehidupan merupakan suatu bentuk interaksi antara seseorang dengan orang lain. Dalam kehidupan berumah tangga komunikasi antara suami dengan istri begitu juga dengan anak-anak terkait dalam hubungan keluarga yang mana komunikasi interpersonal merupakan suatu bentuk komunikasi yang terjadi antara orang-orang dalam bentuk tatap muka secara langsung yang bersifat intimacy (Littlejohn, 2002). Bahasan lebih lanjut mengenai komunikasi interpersonal yang berkaitan dengan teori CMM (Coordinated Management of Meaning ). Sebagai teori praktis, CMM sebagai teori praktis awal mulanya CMM diterapkan pada proses komunikasi interpersonal yang intim yang digunakan dalam mediasi dan terapi (Cronen \& Pearce, 1985; Cronen, Pearce, \& Tomm. 1985; Shailor, 1994, dalam Pearce \& Pearce, 2000).

Penelitian dalam kajian komunikasi keluarga yang menggunakan teori coordinated management of meaning (CMM) dengan menggunakan teori konstruksi sosial, yaitu penelitian Edith Montgomery (2004) yang mencoba menjelaskan paparan mengenai kehidupan dalam lingkungan keluarga. Secara keseluruhan, penelitian Montgomery (2004) menyatakan bahwa setiap keluarga mempunyai cara yang berbeda-beda dalam mengkomunikasikan pengalaman hidupnya. Model story told dan story lived dalam coordinated management of meanings mampu untuk memahamai fenomena dalam keluarga (Montgomery, 2004). Montgomery (2004) juga menjelaskan bahwa ketika story told dan story lived terjadi kontradiksi, sehingga situasi ambigu dan tidak menentu terjadi. Lebih lanjut, makna menyediakan konteks untuk membuat rasa mengenai sejarah keluarga tentang kekerasan pengasingan dapat koheren atau bertentangan, dan mungkin mengakibatkan penguatan hubungan atau kebingungan, ketidakberdayaan, dan tindakan kelumpuhan.

Pernyataan ini diperkuat oleh pendapat Littlejohn yang menyebutkan bahwa, makna yang diciptakan dan dilanjutkan oleh proses interaksi dalam sebuah kelompok sosial (2001, h. 144). Munculnya pendapat ini, dapat ditarik kesimpulan bahwa CMM berakar dari teori interaksionisme simbolik yang dibangun dengan gagasan bahwa struktur sosial dan makna yang diciptakan dan dipelihara dalam sebuah interaksi sosial (Littlejohn, 2001, h. 145). Berdasarkan pendapat yang disampaikan oleh Littlejohn tersebut, maka secara jelas bahwa manusia membutuhkan manusia lainnya dalam proses interaksi. Interaksi dilakukan oleh manusia dalam kehidupan ini dilakukan secara kontinu dan memiliki tujuan untuk memenuhi kebutuhan dalam berkehidupan sehari-hari. Interaksi yang terjalin secara kontinu ini akan membentuk suatu budaya. Budaya merupakan sauatu cara hidup yang berkembang dan dimiliki bersama oleh sebuah kelompok orang dan diwariskan dari generasi ke generasi (Tubbs \& Moss, 1996, h. 237). Budaya tercipta dari berbagai unsur yang rumit dalam kehidupan masyarakat (Tubbs \& Moss, 1996, h. 237).

Interaksi yang dilakukan secara terus menerus oleh manusia menghasilkan budaya tersendiri dalam kelompok masyarakat yang berada di Indonesia. Menurut para ahli sejarah, Islam masuk di Pulau Jawa pada abad ke VII M atau abad pertama Hijriah, penyebaran secara intensif diawali pada abad ke 13 (Syamsudiin, 1987, h. 185). Hal tersebut diperkuat dengan hasil seminar sejarah masuknya Islam ke Indonesia yang berlangsung mulai tanggal 17 hingga 20 Maret tahun 1963. Kedatangan Islam ke Jawa ini, tidak ada keinginan untuk merusak kedamaian dan ketentraman penduduk pribumi. Jauh sebelum Islam datang ke Pulau Jawa ini, telah tercipta adanya masyarakat, alam fikiran, adat istiadat, dan kebudayaan yang dipengaruhi animisme, dinamisme, Hinduisme dan Budhisme. Dewa-dewa diposisikan sebagai Tuhan atau penguasa tertinggi yang harus disembah dan dipuji. Maka dalam dakwah yang dilakukan "Wali Songo" berusaha mengubah pola pikir masyarakat jaman dahulu. Dewa-dewa yang awalnya dipercaya dijadikan sebagai Tuhan disesuaikan dengan Agama Islam bahwa Dewa memeiliki status yang sama seperti manusia pada umumnya yang tidak boleh disembah, yang boleh disembah hanya Allah SWT (Effendi, 1984, h. 93).

Berbagai macam upaya dilakukan penyair yang memiliki tujuan utama adalah untuk melakukan syiar agama Islam di Pulau Jawa. Mereka melakukan dengan berbagai cara, mulai dari cara keras yang membuat oranglain semakin antipati dengan Agama Islam, namun ada juga yang melakukan syiar agama dengan cara "Bil Hikmah" sehingga Islam dapat tersebar hingga pelosok daerah. Efek dari syiar agama Islam tersebut, maka pemeluk Islam di Indonesia yang khususnya di Pulau Jawa memiliki berbagai macam sebutan diantaranya : sinkreitisme, accomadations, modernis, reformist militant, dan Islam Kejawen (Munawir,1980, h. 291). Pada masa selanjutnya. Lahirlah aliran kebatinan dan kepercayaan yang dianggap dapat menangkal tanggapan negatif terhadap ajaran agama yang dirasakan, karena tidak mampu menyelesaikan permasalahan yang ada. Seiring berjalannya waktu, maka aliran kepercayaan serta kebatinan tumbuh dan berkembang dimana-mana.

Pada awal kemerdekaan Negara Republik Indonesia hingga tahun 1950, aliran kepercayaan dan kebatinan di seluruh Indonesia berjumlah sebanyak 70 aliran. Namun pada tahun $1912 \mathrm{M}$ jumlah itu meningkat semakin pesat menjadi 644 aliran. Bangkitnya aliran kepercayaan dan kebatinan ini disebabkan karena ketidakpuasan para pendiri aliran kepercayaan dan kebatinan terhadap ajaran yang ada. Kekecewaan mereka terhadap agama memiliki beberapa alasan diantaranya ; 1) Agama dirasa tidak mampu menciptakan perdamaian dunia sekalipun keberadaannya sudah ribuan tahun. Hal ini terbukti dengan adanya konflik serta peperangan antar agama dan intern agama, 2) Agama dirasa tidak mampu memberikan ketenangan batin dan ketenangan hidup sehari-hari secara menyeluruh. Semua ini berdasarkan pada ritualritual agama yang mengganggu orang lain, seperti suara bedug, dan adzan, 3) Agama dirasa tidak menanamkan atau mengutamakan terbentuknya kepribadian yang berbudi luhur, hal ini menyebabkan agama tidak berhasil menciptakan 
perdamaian dunia terutama dalam kehidupan bermasyarakat serta masih adanya pemeluk agama yang tidak berbudi luhur, 4) Agama bukan merupakan asli milik bangsa Indonesia, Islam adalah milik bangsa Arab, Kristen milik bangsa Barat, dan bangsa Indonesia aslinya adalah kepercayaan dan kebatinan atau leluri leluhur (Ilyas \& Imam, 1988, h. 168-170).

Disamping berbagai anggapan yang dijelaskan sebelumnya, masih ada berbagai faktor-faktor yang mempengaruhi munculnya aliran kepercayaan dan kebatinan diantaranya ; 1) Faktor ekonomi Orang penganut agama Islam, tetapi dengan agama Islam mereka kehidupannya kurang makmur, kemudian ada guru yang memberikan petunjuk sehingga orang itu berhasil, 2) Tekanan Feodalisme Tekanan dari para penguasa, kemudian orang mencari ketenangan supaya tidak tertekan. Bagi orang yang tidak kuat agamanya supaya harga dirinya bisa naik dan berubah kemudian orang beralih ke aliran kepercayaan, 3) Prihatin dalam masyarakat Jawa ada yang dinamakan prihatin dengan maksud untuk mengendalikan nafsu karena hawa nafsu tidak disenangi (Sutomo \& Ma'ruf, 1987, h. 126-127).

Dengan adanya berbagai asumsi yang disebutkan diatas, maka muncullah aliran kepercayaan dan kebatinan untuk menyumbangkan dharma baktinya demi mewujudkan masyarakat yang damai dan tentram yang didasari dengan budi yang luhur. Pemahaman dan praktek agama yang dilakukan oleh salah satu keluarga (Niti Giman) di Kab. Mojokerto sesuai dengan penjabaran yang telah dijelaskan sebelumnya. Menariknya dalam ini adalah mereka mengklaim Islam yang benar adalah apa yang mereka lakukan dan apa yang mereka pahami sesuai dengan panutan serta penafsiran yang mereka anut pada dasarnya bukan dari ajaran agama Islam yang sebenarnya. Kehidupan masyarakat di Kab. Mojokerto, Dusun Pucuk, Kec. Ndawarblandong belum mampu menggambarkan layaknya umat Islam yang berkeyakinan pada ajaran Islam yang benar. Terbukti dengan banyaknya umat Islam yang masih lemah dalam menjalankan syariat dengan melakukan pelanggaran yang tidak sesuai dengan ajarannya.

Berbeda dengan penelitian Hendropuspito, menyebutkan bahwa dalam agama seharusnya mampu untuk menyeleksi kaidah-kaidah susila yang ada dan mengukuhkan yang baiks erta meninggalkan kaidah yang buruk (Hendropuspito, 1983, h. 45). Menurut deskripsi diatas, peneliti membuat kesimpulan. Perlu adanya penelitian terkait dengan Proses Konstruksi Ilmu Sejati Orangtua kepada Anggota keluarga. Terkait dengan kesimpulan tersebut yang memunculkan suatu keinginan peneliti. Bagaimana Proses Konstruksi Ilmu Sejati Orangtua kepada Anggota keluarga di Era Modern.

\section{TINJAUAN PUSTAKA}

\section{a. Teori Konstruksi Sosial}

Berger dan Luckman memandang masyarakat sebagai proses yang berlangsung dalam tiga momen dialektis yang simultan, yaitu eksternalisasi, objektivasi dan internalisasi serta masalah legitimasi yang berdimensi kognitif dan normatif, inilah yang dinamakan kenyataan atau realitas sosial. Hal itu merupakan suatu konstruksi sosial yang diciptakan sendiri oleh manusia berdasarkan realitas sosial dalam perjalanan sejarahnya dari masa silam, kemasa kini dan menuju masa depan (Sriningsih, 2010, h. 143). Teori ini beranggapan bahwa manusia yang merupakan bagian dari masyarakat menciptakan dunia dan realitas sosialnya sendiri. Hal tersebut menunjukkan bahwa manusia pencipta dari dunianya sendiri. Manusia dalam banyak hal mempunyai kebebasan untuk bertindak diluar batas kontrol struktur dan pranata sosialnya, dimana individu itu sendiri berasal. Manusia secara efektif dan kreatif mengembangkan dirinya melalui responrespon terhadap stimulus atau dorongan dalam dunia kognitifnya (Bungin, 2001, h. 3).

\section{b. Teori Pola Komunikasi Keluarga Fitzpatrick}

Penelitian yang dilakukan oleh Fitzpatrick dkk menetapakan dua orientasi yang menjadi dasar untuk membangun hubungan komunikasi dalam keluarga (Odenweller, Ritteneour, Myers, Brann, 2011). Dua orientasi tersebut yang akan menentukan pola komunikasi dalam sebuah keluarga (Littlejohn, 2009; Berger, dkk., 2015). Dua hal yang terdapat dalam teori komunikasi keluarga tersebut diantaranya adalah orientasi percakapan dan orientasi ekpatuhan (Khani, Fard, Broodmend, 2015). Koernern \& Fitzpatrick dalam Vangelisti (2004) menyatakan bahwa dua dimensi tersebut merupakan struktur dasar kepercayaan perilaku dalam komunikasi keluarga.

\section{c. Teori Coordinated Management Of Meaning (CMM)}

Teori manajemen makna terkoordinasi atau coordinated management of meaning (CMM) dikembangkan oleh V.E Cronen dan W.B Pearce pada tahun 1970-an. Teori ini menggabungkan beberapa kajian dari beberapa bidang termasuk sistem teori, interaksionisme simbolik, konstruksi sosial, tindak tutur, dan komunikasi hubuungan (Littlejohn, 2002 , h. 171). Teori ini memiliki peran dalam membantu kita untuk memahami proses pemaknaan dan tindakan (Littlejohn \& Foss, 2009, h. 255). Teori CMM awalnya bermula dari teori interpretatif yang fokus utamanya pada komunikasi interpersonal (Gudykunts, 2005, h. 37; Pearce \& Pearce, 2000).

\section{d. Teori Tindak Tutur (Speech Act Theory)}

Teori ini digunakan untuk membanti kita dalam memahami bagaimana manusia menyempurnakan tindakan dengan kata-katanya (Littlejohn \& Foss, 2009, h. 163). Teori ini dikenalkan oleh J.L Austin dalam sebuah perkuliahan yang dikenal dengan The William James Lecturers di Universitas Harvard pada tahun 1955 dan dri bukunya yang berjudul How To Do Things With Word pada tahun 1962. Teori ini dibangun berdasarkan keyakinan bahwa kata-kata memiliki pengaruh yang sama dengan tindakan atau dengan kata lan, kata-kata akan menimbulkan dampak yang kuat sekuat 
tindakan yang dilakukan pada oranglain (Al-Omari \& Abu Melhim, 2013). Tokoh lain yang mengembangkan teori ini adakah H.P Grice yang berpendapat bahwa makna dalam setiap komniksi dipandang sebagai sebuah represntasi dari niat penutur trehadap pendengar.

\section{METODE PENELITIAN}

Pendekatan dalam penelitian Konstruksi Ilmu Sejati Orangtua kepada anggota keluarga ini adalah pendekatan Fenomenologi dengan model Coordinated Management of Meaning. Penelitian kualitatif ini menggunakan teori Manajemen Makna Terkoordinasi (Coordinated Management of Meaning) untuk menganalisa pengalaman penurunan nilai komunitas "Ilmu Sejati” yang berada di Kab. Mojokerto Desa Pucuk, Kec. Ndawarblandong Wotgaru, Jawa Timur. Teori CMM ini digunakan untuk menjelaskan bagaimana penurunan pesan-pesan atau nilai-nilai Orangtua kepada anakanaknya sehingga dapat diterapkan menjadi nilai dari kehidupan di Era Modern saat ini.

Dalam penelitian ini peneliti melakukan pengamatan secara langsung mengenai kehidupan keluarga "Ilmu Sejati" di kab. Mojokerto, Desa. Pucuk, Kec. Ndawarblandong Wotgaru, Jawa Timur. Dalam penelitian ini, realitas didapatkan melalui pemahaman pengalaman dan konteks interaksi antara orangtua dan anggota keluarga penganut aliran kepercayaan Ilmu Sejati di Mojokerto. Penelitian ini menganalisis konstruksi orangtua dengan anggota keluarga dengan pendekatan model CMM, studi fenomenologi pada salah satu keluarga penganut aliran kepercayaan Ilmu Sejati di Dusun Pucuk Kec. Ndawarblandong Kab. Mojokerto. Penelitian ini menggunakan teori CMM dalam analisisnya.

Dalam melakukan penelitian, peneliti terlibat langsung dalam berbagai konteks interaksi dengan informan, yang merupakan anggota keluarga penganut Ilmu Sejati di Kab. Mojokerto Dusun Pucuk, Kec. Ndawarblandong yang tengah menjalankan ajaran Ilmu Sejati. Data-data yang diadapat dalam penelitian ini adalah hasil dari interkasi dengan anggota penganut ajaran Ilmu Sejati. Penentuan jumlah informan atau sampel pada penelitian ini didasarkan purposive sampling ditentukan mengacu pada kriteria yang dibuat oleh peneliti. Kegiatan-kegiatan ritual yang baisa dilakukan oleh anggota Ilmu Sejati ini dilakukan bersama-sama setiap bulannya terjadi 3-4 kali. Tepatnya pada tanggal 9, 11, 22. Dalam Samovar dkk (2010, h. 67) dijelaskan bahwa keluarga besar terdiri dari keluarga inti yang terkait dan berkumpul dalam sebuah unit domestik yang lebih besar. Menurut Sugiyono (2007, h. 293) menyatakan sampel sebagai informan sebaiknya memenuhi kriteria sebagai berikut; 1) Mereka yang memahami serta menguasai sesuatu melalui proses enlkulturasi, sehingga sesuatu bukan sekedar diketahui tetapi juga dihayati, 2) Mereka yang tergolong masih sedang berkecimpung atau terlibat langsung pada kegiatan yang tengah diteliti, 3) Mereka yang mempunyai waktu yang memadai untuk dimintai informasi. Teknik sampling dalam penelitian ini adalah berdasarkan teknik purposive sampling.

Teknik ini memilih informan berdasarkan kriteria tertentu yang telah ditetapkan untuk mendapatkan tujuan penelitian. Beberapa kriteria yang ditentukan oleh peneliti sebagai berikut : 1) Anggota keluarga Niti Giman penganut ajaran Ilmu Sejati, 2) Laki-laki/ Wanita berusia 30-73 Tahun. Penelitian ini dilakukan di Kabupaten Mojokerto dusun Pucuk. Kec. Ndawarblandong. Lokasi ini dipilih karena daerah ini memiliki komposisi penduduk yang homogen yang sebgian besar bekerja sebagai petani, pedagang dan juga guru, bisa dikatakan kalangan menengah kebawah. Mojokerto diasumsikan merupakan daerah yang memiliki potensi perkembangan yang tinggi. Letak berdekatan dengan Kota Surabaya sebagai ibukota dinilai menjadi acuan yang sangat mumpuni mengenai kondisi sosial politik di Jawa Timur. Dan letaknya juga berdekatan dengan Kota Gresik. Selain itu di kabupaten Mojokuto, dusun Picik, Kecamatan Ndawarblandong ini keadaan masyarakat cenderung masih tradisional karena para opinion leader di Dusun ini merupakan orang Jawa Asli tidak menyetujui jika ada masyarakat berkulit putih (China) membuka usaha disekitar dusun Ndawar Grandong, sehingga kultur pemikiran masyarakat pun terbentuk sangat sulit untuk diajak berkembang ke arah modern.

Penelitian ini menggunakan dua jenis data yaitu data primer dan data sekunder diantaranya adalah sebagai berikut: Data Primer yaitu Data yang diambil langsung melalui wawancara mendalam dengan narasumber atau informan yang berhubungan langsung dengan objek penelitian. Dalam penelitian ini, data yang diperoleh dari hasil wawancara mendalam didalam yang terdapat subjek penelitian itu sendiri. Data yang dikumpulakan berupa kata-kata lisan dan hasil interpretasi peneliti dalam mengamati fenomena yang ada pada anggota keluarga aliran kepercayaan Ilmu Sejati. Dalam penelitian ini, peneliti juga mengumpulkan data sekunder dengan orang yang dianggap mengerti dan memahami bagaimana kehidupan keluarga aliran kepercayaan Ilmu Sejati di Mojokerto dan juga melakukan pengambilan data dari penelitian terdahulu yang terkait dengan dunia aliran kepercayaan kejawen. Teknik pengumpulan data yang digunakan dalam penelitian ini adalah wawancara mendalam, observasi, dan dokumentasi. Peneliti ini menggunakan In-depth interview dimana proses memperoleh keterangan untuk tujuan penelitian dilakukan dengan cara tanya jawab dengan bertatap muka secara langsung antara pewawancara dengan informan, dengan atau tanpa menggunakan pedoman wawancara, (interview guide), yang difokuskan pada unit analisis yang akan diteliti. Dokumentasi, data primer dalam hal ini yaitu berupa penget (pedoman ilmu sejati), buku laporan setiap pelajaran, dokumen Ilmu Sejati, buku-buku yang terkait dengan ajaran Ilmu sejati.

Teknik selanjutnya yang dilakukan oleh peneliti adalah observasi. Peneliti menggunakan Observasi partisipan dimana peneliti akan terjun langsung berbaur dengan masyarakat penganut ajaran aliran ilmu sejati. Peneliti juga menggunakan teknik wawancara secara tradisional / non formal yang dilakukan secara bertahap dari awal hingga akhir sehingga posisi peneliti disini lebih berbaur dan bersifat flued sehingga objek tidak merasa sedang diteliti serta menggunakan 
bahasa jawa kromo inggil karena kebanyakan masyarakat mojokerto adalah masyarakat yang sangat memperhatikan tutur pitutur serta tindak tanduk dalam berkomunikasi. Keunggulan Teknikini adalah data yang dikumpulkan dalam dua bentuk: interaksi dan percakapan. Artinya, selain perilaku nonverbal juga mencakup perilaku verbal dari orang-orang yang diamati. Dalam penelitian Proses Konstruksi Ilmu Sejati Orangtua kepada Anggota keluarga di Era Modern melalui Komunikasi Keluarga dan Analisis Teori CMM (Coordinated Management of Meaning) ini, peneliti menggunakan teknik observasi partisipan. Teknik dokumentasi digunakan peneliti dalam penelitian ini untuk mendapatkan informasi yang mendukung analisis dan interpretasi data. Ada beberapa dokumen yang sebagian sudah dikumpulkan oleh peneliti, diantaranya berupa penget, buku riwayat \& perkembangan Perguruan Ilmu Sejati, buku pelajaran Perguruan Ilmu Sejati, Hangadungaken yang berisi penejlasan wujud manungso, dan daftar hadir pelajaran Ilmu Sejati. Selain buku, beberapa foto-foto yang terkait pelajaran Ilmu Sejati juga sudah terkumpul.

\section{HASIL DAN ANALISIS}

CMM merupakan teori yang menyediakan kerangka kerja untuk menginterpretasikan kegiatan sehari-hari dan melihat aktivitas dalam interaksi sebagai tempat untuk mencari arti yang dideskripsikan secara kuat dengan tata bahasa (Pawanteh, 1996, h. 64). Sedangkan mendeskripsikan tata bahasa dalam CMM dilakukan dengan cara mengartikan pesanpesan yang berurutan atau koordinasi. Pearce (1989) menyebutkan bahwa koordinasi lebih mudah untuk ditunjukkan daripada dideskripsikan, hal ini dijabarkan oleh West dan Turner sebagai cara terbaik untuk memahami koordinasi adalah dengan mengamati orang-orang yang berinteraksi dalam kehidupan sehari-hari (2008, h.122).

Penjabaran hasil koordinasi dalam penelitian ini akan disajikan pada bagian interpretasi CMM. Interpretasi CMM akan berisi pembahasan terhadap hasil wawancara peneliti terhadap informan yang akan dianalisis berdasarkan komponen-komponen analisis CMM. Interpretasi CMM diantaranya seperti NK (Naskah Kehidupan), PB (Pola Budaya), HB (hubungan), EPI (Episode). Pengumpulan data yang telah didapat oleh peneliti selama melakukan penelitian melalui wawancara mendalam (depth interview) dan pengamatan (observasi) terhadap 1 keluarga yang terdiri dari 6 orang Informan yang mengikuti ajaran Ilmu Sejati di Kab. Mojokerto. Oleh sebab itu, untuk mendapatkan data yang akurat peneliti membatasi jumlah informan.

\section{a. Kisah 1 : Eddy Suprayitno}

Eddy adalah anak ke tiga dari 4 bersaudara. Eddy berasal dari Kota Mojokerto, Desa Pucuk, Kec. Ndawarblandong Jawa Timur. Eddy berprofesi sebagai Dosen di Universitas ternama di Kota Malang. Eddy saat ini berusia 59 Tahun. Eddy memiliki seorang istri yang bernama Titik Dwi Sulistiyati yang juga berprofesi sebagai Dosen. Berdasarkan hasil wawancara yang dilakukan peneliti dengan Eddy Suprayitno yang merupakan anak laki-laki satu-satunya dalam keluarga. Bapak Eddy bernama Niti Giman dan Ibunya bernama Suwarni. Eddy dibesarkan oleh orangtua yang notabene merupakan pengusaha sarung tenun satu-satunya di Kab. Mojokerto. Tidak hanya itu orangtua Eddy juga berprofesi sebagai petani dan juga pedagang. Ibu Eddy ini buta huruf tidak pernah menempuh sekolah, sedangkan bapak dari Eddy ini adalah anak satu-satunya dari keluarga yang berkecukupan. Sejak kecil Eddy dibesarkan dengan didikan orangtua yang sangat otoriter sehingga apa yang diperintahkan oleh orangtua anak-anak tidak boleh membantah dengan alasan apapun. Pada episode ini akan menjelaskan mengenai kronologi awal Eddy ketika diajak bapaknya yang bernama Niti Giman untuk mengetahui Ilmu Sejati yang sedang dianut oleh kedua orangtuanya.

\section{Episode 1 Perkenalan Kehidupan Ilmu Sejati Melalui perayaan ulangtahun Ilmu Sejati}

Pada episode ini menjelaskan mengenai awal mula Eddy diperkenalkan Niti Giman (Orangtua) dengan ajaran Ilmu Sejati ketika berusia 5 tahun menginjak bangku SD (Sekolah Dasar). Proses pengenalan diawali dengan diajak Ayah atau Ibu pada saat kegiatan pelajaran di Perguruan Ilmu Sejati dan ketika mendatangi perayaan Ulangtahun Ilmu Sejati yang diadakan secara rutin setiap tahunnya. Perayaan ulangtahun Ilmu Sejati ini selalu diramaikan dengan pagelaran Wayang Kulit semalam suntuk. Didalam pagelaran wayang ini terdapat makana tersendiri yang disampaikan oleh Dalang melalui media perantaranya berupa Wayang Kulit. Sehingga pagelaran wayang kulit inilah yang sangat dinantikan oleh warga mojokerto. Pada dasarnya desa kelahiran Eddy ini lokasinya sangat terpencil, akses menuju kota pun harus ditempuh dengan jalan yang terjal dihiasi oleh hutan belantara. Untuk memenuhi kebutuhan hiburan pun Eddy harus menunggu setahun sekali ketika perayaan Ilmu Sejati. Berdasarkan wawancara peneliti dengan Eddy, Niti Giman adalah orang yang pertama kali mengenalkan Eddy mengenai pelajaran dalam Ilmu Sejati. Niti Giman adalah ayah kandung dari Eddy. Niti Giman menganut Ilmu Sejati karena orangtua Niti Giman dulunya juga penganut Ilmu Sejati.

$\mathrm{S}: \mathrm{Pa}$, maaf lagi sibuk ta?

$\mathrm{P}$ : Ora nduk, ono opo kok sawangane penting?

$\mathrm{S}$ : Ndak Pa, Shita penasaran sama cerita e Papa awal mula pas Mbah Kung ngejak papa ngikut Ilmu Sejati seperti apa pa?

P : Awal mulae papa nggak paham sekali mengenai ajaran Ilmu Sejati nduk. 
$\mathrm{S}$ : Loh, Ilmu Sejati iku yang dianut sama Mbahkung dan Mbahti ket biyen ta Pa?

P : Iyo mesti ta nduk, wong mbah e Papa dulu yo nganut Ilmu Sejati, dadi yo nggak salah kalau anaknya (Mbahkung) mengikuti kemauan orangtuanya.

$\mathrm{S}$ : Oalah gitu to ceritane. La terus awalnya gimana Pa kok bisa papa diajak?

$\mathrm{P}$ : Awal mula e papa iling nemen, pas iku papa sik SD Papa dijak Mbahkung unjung-unjung ke tempat pelajaran Ilmu Sejati sing tempate disebelah selepanne mbah. Terus nek ono ulangtahun Ilmu Sejati Papa selalu diajak mbah soale mesti dirayakan karo nanggap wayang dan pastine acarane meriah dan akeh sing nonton.

$\mathrm{S}$ : Pas pelajaran iku isine opo ae $\mathrm{Pa}$ ?

P : Papa waktu itu yo mek sukur ngrungokno ae ga paham maksude soale gawe boso jowo sing alus dadi papa durung paham wong papa sek cilik

$\mathrm{S}$ : Terus waktu pagelaran wayang iku ceritone opo Pa? Lakone sopo?

P : Dadi yo ceritane wayang pas iku papa sik iling kisah Dewa Ruci iki intine untuk mendapatkan "inti pengetahuan sejati" (Tirta Prawitasari) Sang Bima harus menempuh ujian fisik dan mental sangat berat, (Hutan Tibaksara "tajamnya cipta"; Gunung Reksamuka, "pemahaman mendalam"). Sang Bimasena tidak akan mampu menuntaskannya tanpa membunuh raksasa Rukmaka "kamukten, kekayaan" dan Rukmakala "kemuliaan". Tanpa mengendalikan nafsu dunianya dalam batas maksimum. Perjalanannya menyelam ke dasar laut diartikan dengan "samodra pangaksami" pengampunan. Membunuh Naga yang mengganggu jalannya simbol dari melenyapkan kejahatan dan keburukan diri. Pertemuannya dengan Sang Dewa Ruci melambangkan bertemunya Sang Wadag dengan Sang Suksma Sejati. Masuknya wadag Bima kedalam Dewa Ruci dan menerima Wahyu Sejati bisa diartikan dengan "Manunggaling Kawula-Gusti", bersatunya jati diri manusia yang terdalam dengan Penciptanya. Kemanunggalan ini mampu menjadikan manusia untuk melihat hidupnya yang sejati. Dalam istilah Kejawen "Mati sajroning urip, urip sajroning mati". (Mati di dalam Hidup, dan Hidup di dalam Mati). Ini adalah esensi dari Kawruh Kejawen. Perjalanan tasawuf untuk menukik ke dalam dirinya sendiri. Lakon ini menjadi berat, karena cerita di dalamnya mengandung jalan kontemplasi tentang asal dan tujuan hidup manusia (sangkan paraning dumadi), menyingkap kerinduan akan Tuhan dan perjalanan rohani untuk mencapaiNya (manunggaling kawula Gusti).

S : Waduh abot yo Pa ceritane.

P : Yo ngono iku cerito wayange nduk. Lha ket cilik wes dibiasakno mbah ndelok wayang dadi smpe Papa tuwek ngene yo seneng nemen karo wayang. Coba arek saiki nek dikongkon milih ndelok wayang op bioskop pasti milih ndelok bioskop ya to?

$\mathrm{S}$ : Yo mesti ta $\mathrm{Pa}$, arek jaman saiki ngno kekinian mikir wayang iku gak asik tontonan e wong tuwek dan mboseni. Padahal nek paham karo alur ceritone wayang iku lebih apik dibanding film-film ndek bioskop.

P : Tak terusno maneh yo Ilmu Sejati iku ben tahun e ngrayakno ulangtahun mesti nanggap wayang kulit.

\section{Interpretasi CMM}

Cuplikan wawancara yang ditampilkan diatas dipilih karena menceritakan awal kisah perjalanan Eddy ketika diajak Niti Giman (ayahnya) untuk mengunjungi pagelaran wayang kulit yang diadakan ketika perayaan Ulang Tahun Ilmu Sejati. Dalam cuplikan wawancara diatas, Eddy menjelaskan awal mula mengetahui ajaran Ilmu Sejati melalui Niti Giman sebagai ayah kandungnya. Berdasarkan wawancara dengan Eddy dalam perayaan Ulang Tahun Ilmu Sejati ini dirayakan secara meriah dengan menggelar pegelaran wayang kulit yang dilakukan rutin setiap tahunnya. Dalam pagelaran wayang kulit tersebut terdapat esensi yang dapat diambil bahwasanya dari cerita Dewa Ruci dapat ditarik benang merah mengenai Kemanunggalan ini mampu menjadikan manusia untuk melihat hidupnya yang sejati. Dalam istilah Kejawen "Mati sajroning urip, urip sajroning mati". (Mati di dalam Hidup, dan Hidup di dalam Mati). Ini adalah esensi dari Kawruh Kejawen. Perjalanan tasawuf untuk menukik ke dalam dirinya sendiri. Lakon ini menjadi berat, karena cerita di dalamnya mengandung jalan kontemplasi tentang asal dan tujuan hidup manusia (sangkan paraning dumadi), menyingkap kerinduan akan Tuhan dan perjalanan rohani untuk mencapaiNya (manunggaling kawula Gusti). Dalam CMM, terdapat Deontic Operators, yang akan mengidentifikasi kekuatan moral yang didefinisikan dalam dua bagian yaitu pilihan secara sadar (conscious choice) dan berkaitan dengan segala tindakan yang bukan merupakan pilihan secara sadar (unconscious choice) (Pawanteh, 1996, h. 85). Tindakan yang dilakukan Eddy ini merupakan conscious choice yang termasuk dalam pilihan yang tidak dapat ditentukan (undetermined) karena Eddy memilih secara sadar untuk mengikuti kemauan bapaknya Niti Giman untuk mendatangi pagelaran wayang kulit dalam perayaan Ulangtahun Ilmu Sejati.

\section{$\underline{\text { Niti Giman }}$}

PB Mulai membiasakan anak untuk mengikuti ritual Ilmu Sejati yang dilakukan setiap tahunnya dengan menggelar Wayang Kulit untuk merayakan Ulang Tahun Ilmu Sejati

NK Orangtua penganut aliran kepercayaan Ilmu Sejati yang selalu berupaya untuk mengajak anaknya bergabung dalam ajaran Ilmu Sejati

HUB Orangtua dengan anak

EPI Memperkenalkan Ilmu Sejati sejak dini 
Ortu Penganut Aliran kepercayaan Ilmu Sejati Memperkenalkan Ilmu Sejati Sejak dini ke anaknya

Mengikuti kemauan ortu Untuk Mengenal Ilmu Sejati
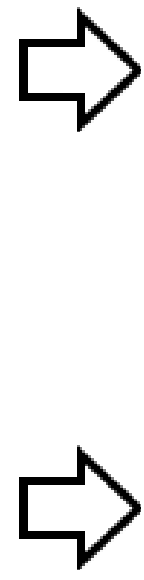

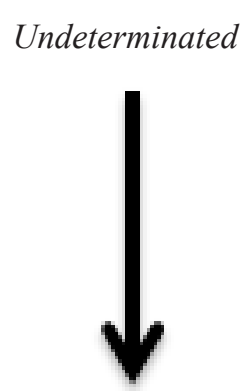

mengikuti kemauan ortu melihat pegelaran wayang kulit dalam rangka Ultah Ilmu Sejati tidak mengetahui motif ortu mengajak melihat wayang kulit

PB Mengikuti anjuran Bapak Niti Giman untuk mengikuti ritual Ilmu Sejati dengan mendatangi pagelaran wayang dalam rangka Ulangtahun Ilmu Sejati yang diadakan secara rutin setiap tahunnya

HUB Anak dengan orangtua

NK perasaan bingung tidak mengenal satu sama lain dan ketakutan karena ajakan orangtua yang mendidik anak secara otoriter satu

EPI Diperkenalkan kehidupan Ilmu Sejati

\section{Eddy}

Figur 4.2.1 Perkenalan Kehidupan Ilmu Sejati Melalui perayaan ulangtahun Ilmu Sejati

\section{KESIMPULAN}

Pendekatan Coordinated Management of Meaning (CMM) yang digunakan dalam penelitian ini membantu untuk menganalisa mengenai fenomena Proses Konstruksi Ilmu Sejati Orangtua kepada Anggota keluarga di Era Modern melalui Komunikasi Keluarga dan Analisis Teori CMM Coordinated Management of Meaning pada salah satu keluarga di Kab. Mojokerto, Desa. Pucuk, Kec. Ndawarblandong). Teori ini menyajikan kerangka kerja yang lengkap dan detail dalam menginterpretasikan peristiwa-peristiwa yang dialami oleh anggota keluarga mengenai ajaran Ilmu Sejati. Teori CMM memiliki tiga kunci utama dalam menganalisis suatu fenomena diantarannya adalah makna dan tindakan, koordinasi dan kisah. Berdasarkan prinsip makna dan tindakan, dapat diketahui bahwa interaksi yang terjadi pada anggota keluarga penganut Ilmu Sejati dimulai ketika mereka melakukan interaksi dengan orangtua mereka dan kemudian diperkenalkan dengan rekan seperguruan Ilmu Sejati. Hubungan ini meruapakn hubungan persahabatan antara orangtua dengan rekan seperguruan Ilmu Sejati. Hubungan ini terjadi karena adanya proses koordinasi makna sehingga membentuk suatu hubungan dan menghasilkan bentuk-bentuk interaksi yang berupa kerjasama, akomodasi, dan juga konflik. Konflik terjadi dalam penelitian ini ketika evolusi hubungan yang mengarah pada perpecahan hubungan dan adanya kegagalan dalam proses mengkoordinasikan makna sehingga terjadi konflik.

Konflik dalam penelitian ini disebabkan adanya proses ketika anak mendapatkan pengetahuan mengenai agama Islam beserta cara ibadah yang dilakukan tidak sejalan dengan yang disampaikan serta diajarkan Orangtua mereka ketika berada dirumah. Simpulan dari penelitian ini adalah pada akhirnya keputusan orangtua untuk mengajak anak-anaknya bergabung mengikuti ajaran Ilmu Sejati adalah akan tercapai koordinasi pada tingkat tertentu, namun didalamnya sangat tidak mudah dengan adanya konflik antara orangtua dan anak-anaknya yang memiliki pandangan yang berbeda mengenai keyakinan. Saran yang diharapkan peneliti diantaranya; 1) Pentingnya untuk dilakukan penelitian mengenai komunikasi keluarga di ASIA yang menggunakan prsepektif Non Western, 2) Peneliti menyarankan untuk dilakukan penelitian sejenis pada kelompok sosial selain keluarga penganut Ilmu Sejati untuk mengetahui perkembangan aliran kebatinan di era Modern saat ini dalam komunikasi keluarga, 3) Penelitian ini dilaksanakan di salah satu wilayah di Jawa Timur yang erat kaitannya dengan budaya Jawa atau kejawen, peneliti berasumsi perlu dilakukan penelitian yang sama pada daerah lain, 4) Masih banyak dokumen, teks-teks klasik yang menyimpah mengenai sejarah Ilmu Sejati, mengenai pendirinya serta biografi serta perkembangan ajaran Ilmu Sejati saat ini, 5) Penting dilakukan penelitian lebih lanjut mengenai sikap perilaku pelaku komunikasi keluarga penganut Aliran kepercayaan lainnya yang disesuaikan dengan ajarannya serta bisa mengidentifikasi melalui komunikasi prespektif Asia. 


\section{DAFTAR PUSTAKA}

Berger, C. R., Roloff, M.E., \& Ewoldsen, D. R. R. (2015). Handbook Ilmu Komunikasi. Bandung. Nusa Media

Bungin, B. (2007). Sosiologi Komunikasi: Teori, Paradigma dan Diskursus Teknologi Komunikasi DI Masyarakat, Jakarta: Kencana. 48-49

Denzin and Lincoln. (2000). "Handbook of Qualitative Research", Sage Publication. London.

Effendi, Zarkasi. (1984). Unsur-unsur Islam Dalam Pewayangan. Bandung : Al-Ma’arif.

Fitzpatrick, M. A. (2004). Family Communication Patterns Theory: Observations on its development and application. Journal of Family Communication, 4 (3/4), 167-179.

Gudykunts, W. B. (2005). Theorizing About Intercultural Communication. Thousand Oaks. CA. Sage Publication

Ilyas, A.M. \& Imam, A.G. (1988). Aliran Kepercayaan dam Kebatinan di Indonesia. Surabaya: CV Amin.

Kriyantono, Rachmat. (2012). Teknik Praktis Riset Komunikasi. Jakarta : Kencana Prenada Media.

Littlejohn, Stephen W. (2001). Theories of Human Communication (7th Ed). Belmont, CA : Wadsworth Thomson Learning.

Littlejohn, Stephen W. (2002). Theories of Human Communication (5th ed). NY: Wardsworth.

Littlejohn, S. W \& Foss, K. A. (2009). Teori Komunikasi Edisi 9. Jakarta. Salemba Humanika.

Montgomery. Edith. (2004). Tortured Families : A Coordinated Management of Meaning Analysis. Family Process, 43 (3), 349-371.

Munawir, Imam. (1980). Kebangkitan Islam dan Tantangan-tantangan Yang dihadapi Dari Masa ke Masa. Surabaya: Pustaka Progresif.

Odenweller, K. G., Ritteneour, C. E., Myers, S. A., \& Brann, M. (2011). Fthe- Son Family Communication Pattens and Gender Ideologies: A Modelling and Compensation Analysis. Journal of Family Communication, 13 (4), $340-357$.

Pawanteh, Latiffah. (1996). Stories of Sojourn: A CMM Analysis of the Intercultural Interaction of Malay Women. Massachusetts, University of Massachusetts Amherst. Disertasi

Pearce, W. B., \& Pearce, Kimberly A. (2000). Extending the Theory of the Coordinated Management of Meaning (CMM) Through a Community Dialogue Process. International Communication Association : Communication Theory, 10 (4), 405-423.

Sriningsih, E. (2010). Anatomi dan Perkembangan Teori Sosial, Yogyakarta: Aditya Media. 143

Sutomo, A, H, \& Ma'ruf, M. A. (1978). Perbandingan Ajaran Sufi dan Kebatinan Jawa. Surabaya : Bina Indra Karya

Syam, Nur. (2005) Islam Pesisir, Yogyakarta: LKis Pelangi Aksara. hal.44.

West, Richard \& Turner, Lynn H. (2008). Pengantar Teori Komunikasi: Analisis dan Aplikasi, Edisi 3, Buku 1, terj. Maria Natalia Damayanti Maer. Jakarta: Salemba Humanika. 